The following article has been retracted.

For details of the retraction please see:

http://www.molecular-cancer.com/content/2/1/17 
Research

\title{
Association of Ataxia Telangiectasia Mutated (ATM) gene mutation/deletion with Rhabdomyosarcoma
}

\author{
Peilin Zhang*1, Kunjan S Bhakta ${ }^{2}$, Pier Lorenzo Puri2, Robert O Newbury4, \\ James R Feramisco ${ }^{3}$ and Jean Y Wang 2,3
}

Address: ${ }^{1}$ Department of Pathology, West Virginia University Health Sciences Center, Medical Center Drive, PO box 9203, Morgantown, WV 26506, USA, 2 Biology, University of California at San Diego, La Jolla, CA 92093-0332, USA, ${ }^{3}$ Cancer Center, University of California at San Diego, La Jolla, CA 92093-0332, USA and ${ }^{4}$ Department of Pathology, The Children Hospital of San Diego, 3020 Children's Way, San Diego, CA 921234282, USA

Email: Peilin Zhang* - pzhang@hsc.wvu.edu; Kunjan S Bhakta - kbhakta@ucsd.edu; Pier Lorenzo Puri - plorenzo@salk.edu; Robert O Newbury - rnewbury@chsd.org; James R Feramisco - jferamisco@ucsd.edu; Jean Y Wang - jywang@ucsd.edu

* Corresponding author

This article is available from: http://www.molecular-cancer.com/content/2/1/2

(C) 2003 Zhang et al; licensee BioMed Central Ltd. This is an Open Access article: verbatim copying and redistribution of this article are permitted in all media for any purpose, provided this notice is preserved along with the article's original URL.

\begin{abstract}
Background: Rhabdomyosarcoma is a common malignancy in children. There are two major types of rhabdomyosarcomas, the embryonal and the alveolar, differing in cytogenetic and morphologic features. The alveolar type of rhabdomyosarcoma is frequently associated with chromosome translocation $\mathrm{t}(2,13)$ and poor clinical prognosis. Pathogenesis of rhabdomyosarcoma remains obscure, and especially it occurs in the location where skeletal muscle is absent. We report here that there is a high frequency of association of rhabdomyosarcoma with ataxia telangiectasia mutated (ATM) gene mutation/deletion.
\end{abstract}

Result: Totally 17 cases of rhabdomyosarcoma specimens were studied by immunohistochemical or immunofluorescent staining with ATM antibody and revealed that 7 of the 17 cases were negative for ATM expression (4I\%). Further analyses of rhabdomyosarcoma cell lines with RT-PCR revealed that in Rh30 cells, an alveolar rhabdomyosarcoma cell line, there are three separate deletions/mutations of the ATM mRNA. Western blotting analysis of the Rh30 cellular extract with anti-ATM antibody showed that there is an aberrant form of ATM protein within the Rh30 cells that are smaller than normal control.

Conclusion: These results suggest a link of ATM gene deletion/mutation with rhabdomyosarcoma, and since ATM kinase is a crucial regulatory protein in DNA damage repair signaling pathway, and ATM deletion/mutation may contribute to pathogenesis of rhabdomyosarcoma.

\section{Background}

Rhabdomyosarcoma is a malignant neoplasm of skeletal muscle, and is one of the most common soft tissue malignancies in the children and adolescent population. Histopathologically rhabdomyosarcoma can be divided into two major subtypes, embryonal rhabdomyosarcoma representing about $80 \%$ of the clinical cases, and alveolar rhabdomyosarcoma representing about $20 \%$ of the total cases $[1,2]$. Extensive cytogenetic studies showed that the embryonal rhabdomyosarcomas are generally associated 
with loss of heterozygosity (LOH) for multiple closely linked loci at chromosomal 11p15.5, suggesting inactivation of one or more tumor-suppressor gene(s) in this region $[2,3]$. But the gene involved in this region has yet to be identified. Many other associated mutation or amplification of oncogenes, tumor suppressor genes including p53, K-ras, N-ras and N-myc, etc. are frequently seen, but the roles of these gene mutations/amplifications in pathogenesis of the tumor remain largely unclear [4];[5]. The alveolar subtype of rhabdomyosarcoma, however, is consistently associated with two common chromosomal translocations. Most cases of alveolar rhabdomyosarcoma are associated with a chromosomal translocation $\mathrm{t}(2 ; 13)$ (q35; q14), and less commonly with $\mathrm{t}(1 ; 13)(\mathrm{p} 36 ; \mathrm{q} 14)$ $[6-9]$. The $t(2 ; 13)$ translocation results in fusion of a portion of the Pax3 gene to a portion of the FKHR gene, leading to formation of fusion protein Pax3-FKHR. Pax3 gene encodes a transcriptional factor important in early development program, while FKHR gene encodes another generic transcriptional factor that is widely expressed in mammalian tissues. The $\mathrm{t}(1 ; 13)$ translocation results in formation of Pax7-FKHR. Both Pax3-FKHR and Pax7FKHR were shown to possess more potent transcriptional activity than its original forms $\operatorname{Pax} 3$ and Pax7 [10,11]. How the chimeric fusion proteins contribute to pathogenesis of rhabdomyosarcoma remains unclear.

Ataxia telangiectasia mutated gene (ATM) is a newly identified member of PI3 kinase family that is mutated in human autosomal recessive disease, ataxia telangiectasia (AT) $[12,13]$. ATM gene is large, spanning about $150 \mathrm{kbs}$ of genomic DNA, and is located on chromosome 11q2223. In response to DNA damage agents such as ionizing irradiation and chemical agent cisplatin, ATM kinase is activated, leading to a cascade of kinase reactions regulating cell cycle, apoptosis, and DNA damage repair $[14,15]$. Many downstream target molecules of ATM kinase were so far identified. These target proteins include the c-Abl tyrosine kinase, the p53 tumor suppressor, the Chk1 and Chk2 serine/threoine kinase, the p34 subunit of replication protein A (RPA), Chk1 serine/threoine kinase and NBS1 kinase which is mutated in human autosomal recessive disease Nijmegan breakage syndrome [16-23]. Clinical characteristics of AT patients include hypersensitivity to irradiation, thymic dysplasia, immune defects and higher tendency to develop malignant tumor, suggesting that ATM function is critical in DNA damage repair and tumor suppression. However, up to date, AT patients are not known to develop rhabdomyosarcoma.

In this study, we report an association of human rhabdomyosarcoma with deletion/mutation of ATM gene. This is the first report so far of ATM gene associated with solid malignancy except for the mantle cell lymphoma, a malignant tumor in lymphoid origin. The association of
ATM gene mutation/deletion with rhabdomyosarcoma suggests a link of ATM gene with cancer risk, and ATM kinase may contribute to pathogenesis of rhabdomyosarcoma.

\section{Results}

Totally 17 patients specimen were retrieved from the archived tissue blocks. The clinical characteristics of these patients were listed as in Table 1. Some patient's clinical information was not available at the time of the study. These patients all carried clinical histopathological diagnoses of rhabdomyosarcoma (embryonal or alveolar type), and showed immunostaining positivity for myogenin, a specific skeletal muscle marker. Immunofluorescent or immunohistochemical staining with anti-ATM antibody was performed on the total of 17 specimens, and 7 of the 17 rhabdomyosarcomas were negative for ATM protein $(41 \%)$ (see Table 1 ). Totally 10 of the 17 were positive for ATM kinase (59\%). ATM protein was predominantly located in cytoplasm in the tumor sections and interestingly, predominantly seen in the nuclei in the rhabdomyosarcoma cell line, as those seen with myoD staining (RD cells) (Fig 1 and 2). There is no difference in staining pattern in regard to the subtypes of the rhabdomyosarcomas, namely embryonal or alveolar subtypes.

It is surprising to note that 7 of the17 (41\%) rhabdomyosarcoma specimens stained negatively for the presence of ATM protein. Under the normal condition, ATM expression is ubiquitous. To further confirm the immunostaining results, two different approaches were taken. One was to see if the ATM mRNA is properly transcribed, and another is to directly see the ATM protein itself by Western blotting analysis from the tumors and compare with the normal form. Due to the limited resource of the fresh tumor samples, we turned to the cell culture system and used the well-established rhabdomyosarcoma cell lines. First, we designed eight pairs of oligonucleotide primers encompassing the almost entire coding sequence of ATM mRNA based on the published cDNA sequence (Genbank accession number U33841)[24](Table 2). The primer designing strategy is shown in Fig 3. ATM mRNA is approximately 9.4 kbs in length and contains multiple protein binding domains for its kinase activity and interaction with other cellular proteins (Fig 3). We used reverse transcription-PCR method to analyze five different rhabdomyosarcoma cell lines, RD cells (embryonal), Rh28, Rh30 (alveolar), Rh3, Rh4, and mouse normal myoblast $\mathrm{C} 2 \mathrm{C} 12$ cells. The human foreskin fibroblasts were used as the control cells. The mRNA was isolated from these cells and used for RT-PCR assays. As shown in Fig 4, in normal fibroblasts, RD cells, Rh28 cells, the amplified DNA fragments were identical in regard to the lengths in comparing with the control fibroblasts, whereas in Rh30 cells, two fragments in \#1 and \#7 lanes (0.94 kbs in Lane \#1, and 1.3 


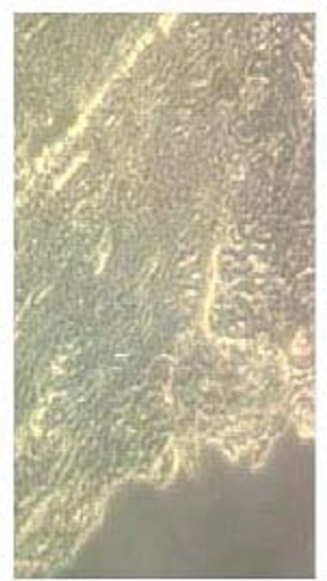

PT1

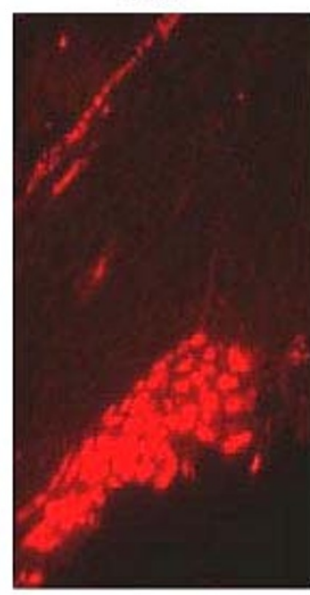

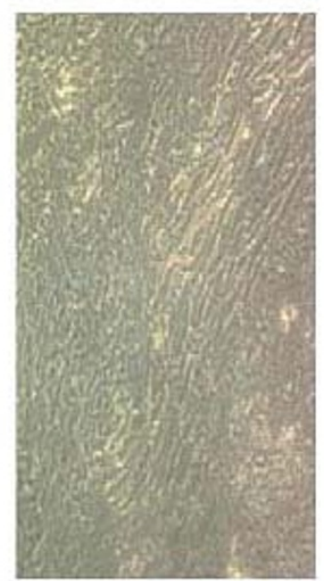

$\mathrm{P}_{12}$

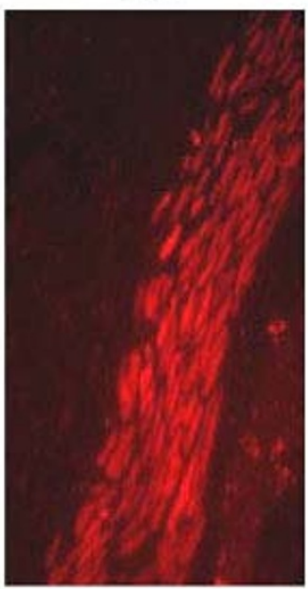

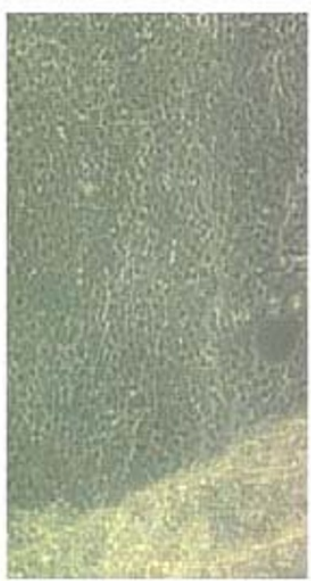

PI3

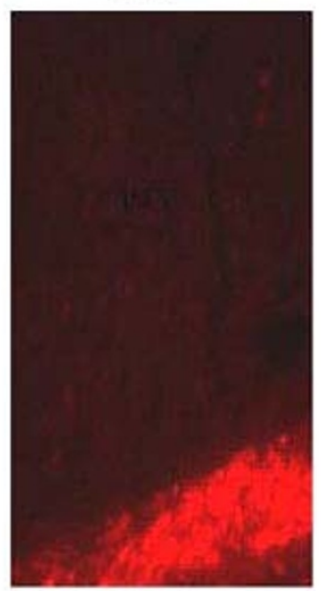

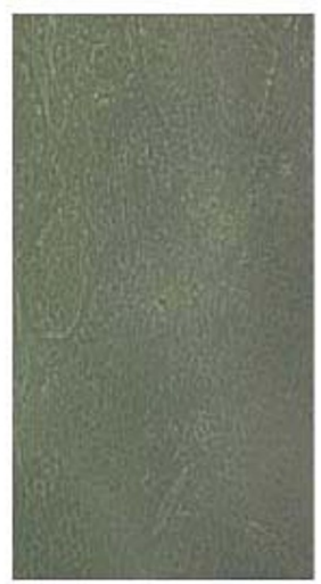

PI4

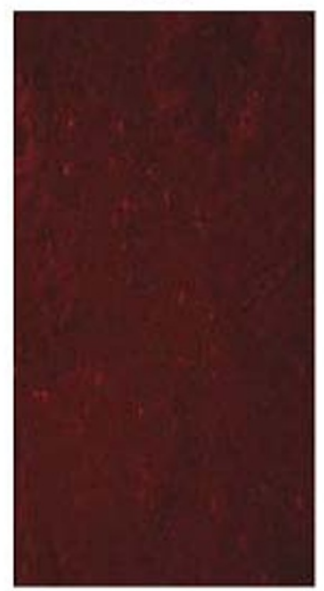

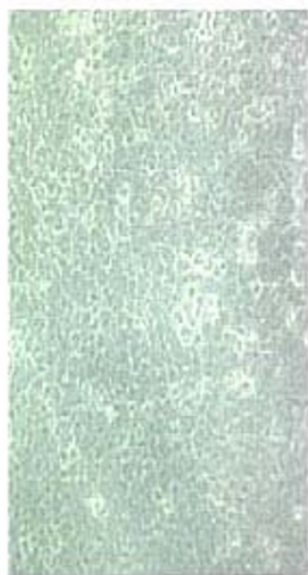

PT5

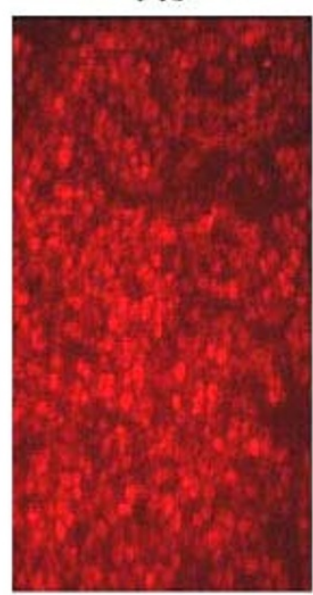

\section{Figure I}

Immunostaining of rhabdomyosarcoma cases. Immunofluorescent staining of five representative cases with anti-ATM antibody. PT: patient. The secondary antibody was conjugated to rhodamine. The photograph was taken at $200 \mathrm{X}$ using Zeiss UV fluorescent microscope.

kbs in Lane \#7) were absent, and in lane \#6, the fragment amplified was approximately 200 bps smaller than that seen in the fibroblasts and other rhabdomyosarcoma cells (Fig 4). The combined length of missing DNA sequence is estimated $2.4 \mathrm{~kb}$ (fragment \#1, plus fragment \#7, and additional 200 bps in lane \#6).

The next question is whether ATM protein is normally translated from ATM mRNA and expressed in the rhabdomyosarcoma cells. We analyzed the ATM protein in different cell lines. In human Hela cells and human normal foreskin fibroblasts, the ATM was estimated to be $360 \mathrm{kD}$, consistent with the results previously described $[12,13]$. In three rhabdomyosarcoma cell lines (RD, Rh28 and RH30), there was one aberrant form of ATM protein ( $260 \mathrm{kD}$ ) that was significantly smaller than that seen in the normal fibroblasts and the Hela cells (Fig 5). The levels of ATM expression in these three rhabdomyosarcoma cell lines are not identical, and Rh30 cells seemed to express less ATM than the other two Rhabdomyosarcoma cells. The murine ATM proteins from C2C12 and 10T 1/2 cells were significantly different in size and there appeared to be two species of ATM proteins in murine cells.

\section{Discussion}

ATM gene is a member of PI3 kinase family. ATM kinase is critical in DNA damage signaling pathway. In response to DNA damage induced by ionizing radiation or chemical agents such as cisplatin, ATM kinase is activated and phosphorylates a number of downstream regulatory proteins important for cell cycle arrest, growth control, apoptosis and DNA repair [25-28]. AT patients are known to 

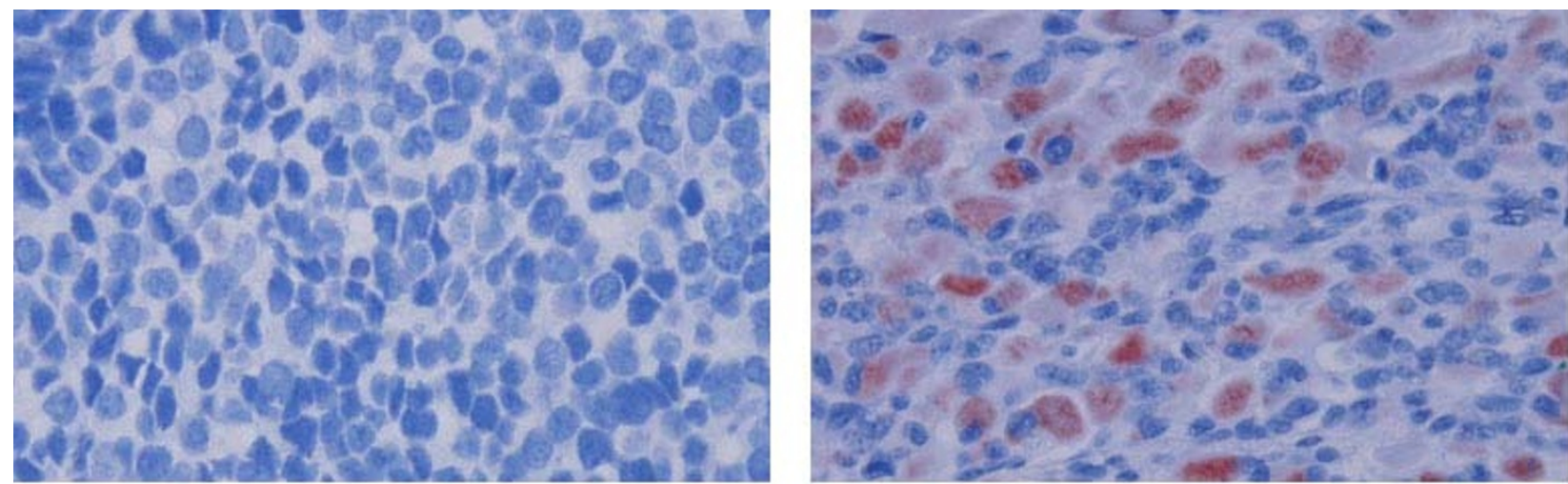

\section{ATM}

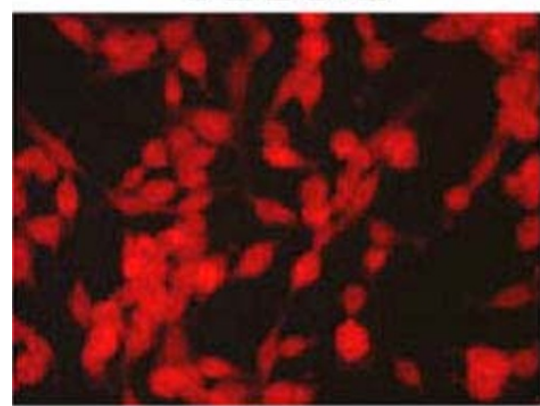

MyoD

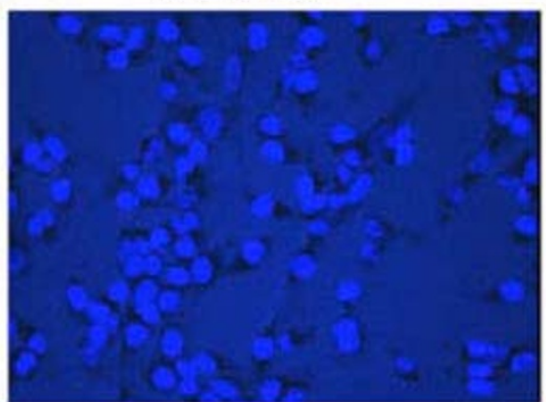

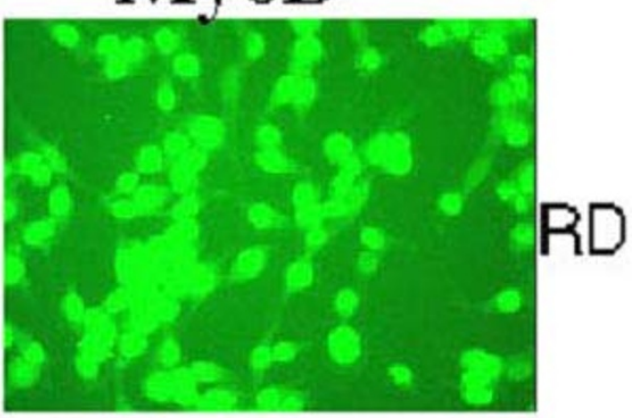

Figure 2

Immunoperoxidase staining of the rhabdomyosarcoma tumor with a negative control. Upper panel represents immunoperoxidase staining of a patient's tumor. The positive staining signals were seen in cytoplasm. The photograph were taken at the magnification of 400X. Lower panel represents immunofluorescent staining of the cultured RD cells with antibodies against ATM and MyoD. The signals were seen in the nuclei. The photograph was taken at 400X.

Table I: RMS Patients and immunostaining profiles

\begin{tabular}{|c|c|c|c|c|}
\hline Case I & I5/M. & Paratesticular & embryona & ATM (-) \\
\hline Case 2 & I9/M. & Prostate/bone marrow & alveolar & ATM (+) weakly/cytoplasmic \\
\hline Case 3 & $4 / \mathrm{M}$ & Salivary gland & embryona & ATM $(+) / C y t o p i a s m i c$ \\
\hline Case 4 & $3 / M$ & Pelvis & embryona & ATM (+)/Cytoplasmic \\
\hline Case 5 & $4 / M$ & Paraspinal & alveolar & ATM (+) weakly/Cytoplasmic \\
\hline Case 6 & $4 / M$ & Skull base & embryona: & ATM (+)/Cytoplasmic \\
\hline Case 7 & $6 / M$ & Abdoman & alveolar & ATM (-) \\
\hline Case 8 & unknown & unknown & alveolar & ATM $(+) /$ Cytoplasmic \\
\hline Case 9 & unknown & unknown & embryona & ATM $(+) /$ Cytoplasmic \\
\hline Case 10 & unknown & unknown & embryona & ATM $(+) /$ Cytoplasmic \\
\hline Case II & unknown & unknown & embryona & ATM (-) \\
\hline Case 12 & unknown & unknown & unknown & $\operatorname{ATM}(-)$ \\
\hline Case 13 & unknown & unknown & unknown & ATM (-) \\
\hline Case 14 & unknown & unknown & lunknown & ATM (-) I \\
\hline Case 15 & unknown & unknown & unknown & ATM (-) I \\
\hline Case 16 & unknown & unknown & unknown & ATM $(+) /$ Cytoplasmic \\
\hline Case 17 & unknown & unknown & unknown & ATM (+)/Cytoplasmic \\
\hline
\end{tabular}




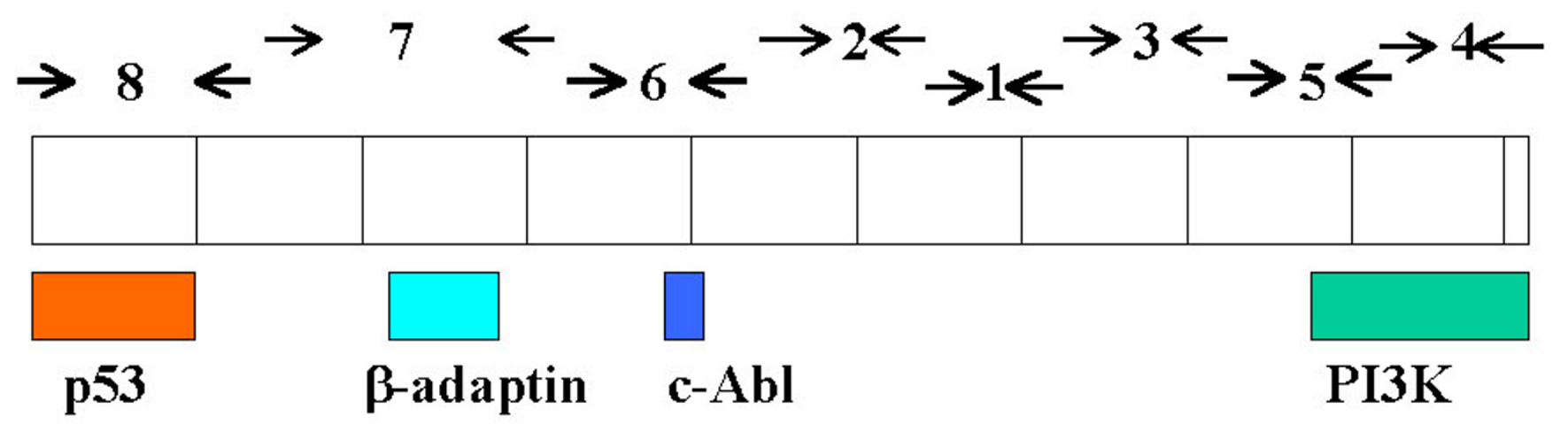

Figure 3

Diagrammatic representation of the ATM protein structure and the RT-PCR strategy. The primer pairs were designed as shown and as listed in Table 2.

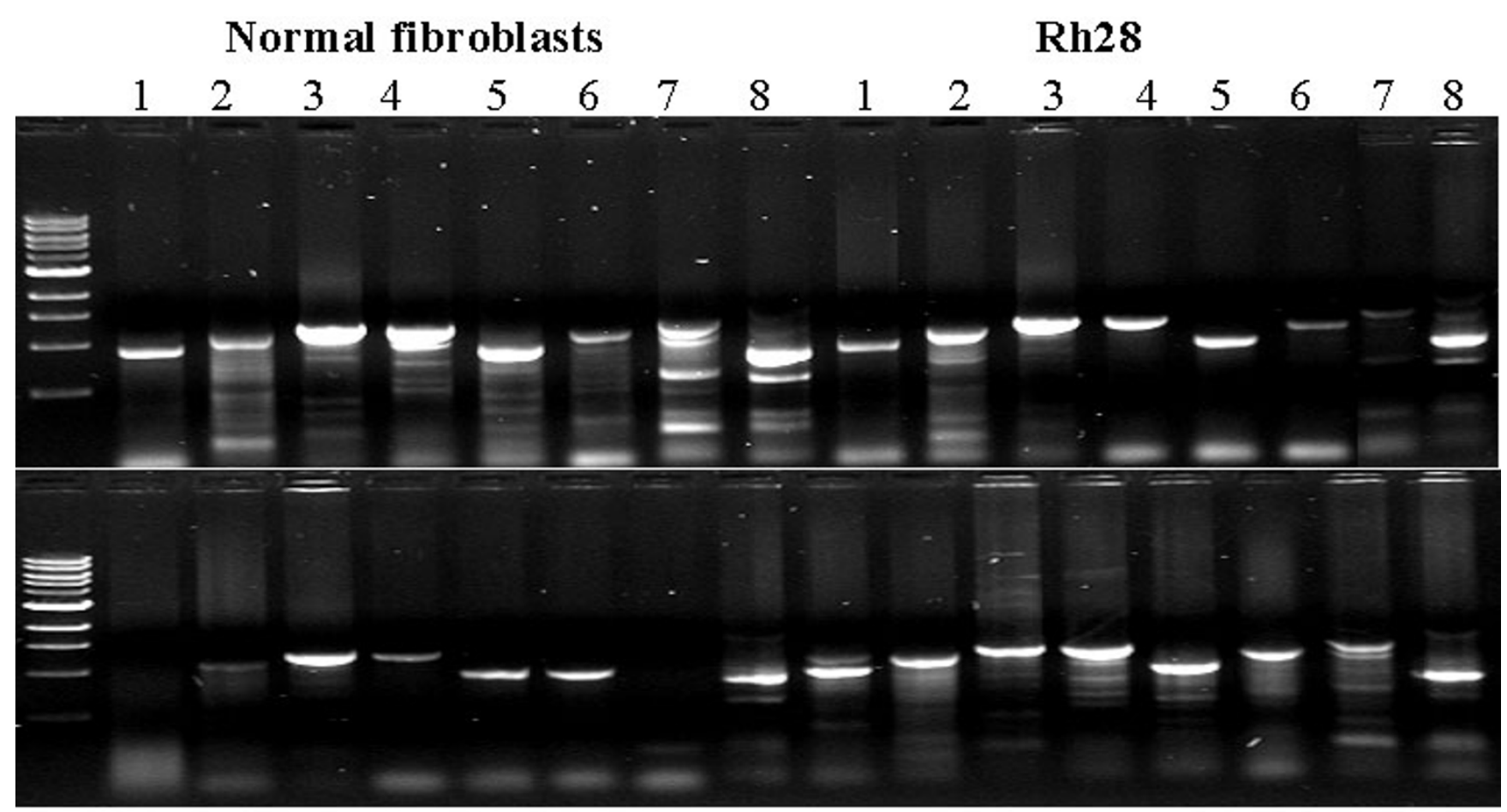

\section{Rh30}

RD

\section{Figure 4}

RT-PCR amplification of ATM mRNA in the different cells using the primer pairs listed in Table2. Human foreskin fibroblasts, human rhabdomyosarcoma cell lines were cultured and the total RNAs were isolated from the cultured cells. The RT-PCR was performed using the total RNA from the cells, and the PCR products were separated on I\% agarose gel and visualized by staining with ethidium bromide. The lengths of the PCR products were compared with each cell line used. 
Table 2: Oligonucleotide primers for RT-PCR amplifications

\begin{tabular}{ll}
\hline Primer & Oligonucleotide sequence $\left(5^{\prime}-3^{\prime}\right)$ \\
\hline IA (exon 36) & CTT CAG TGG ACC TTC ATA ATG C \\
IB (exon 43) & CCA TAC AAA CTA TCT GGC TCC \\
2A (exon 29) & CAG AGA TTG TGG TGG AGT TAT TG \\
2B (exon 36) & GCA TTA TGA AGG TCC ACT GAA G \\
3A (exon 42/43) & CTG GAA TAA GTT TAC AGG ATC TTC \\
3B (exon 5I) & GAT GAT TTC ATG TAG TTT TCA ATT C \\
4A (exon 56) & AAG ATG TTG TTG TCC CTA CTA TG \\
4B (exon 65) & AAG GCT GAA TGA AAG GGT AAT TC \\
5A (exon 5I) & GAT GGA GAA AGT AGT GAT GAG C \\
5B (exon 57) & AGT CAC CAG ATT TCC ATA TTC TC \\
6A (exon 22) & CTA GGT CAA AGC AAT ATG GAC TC \\
6B (exon 30) & CAT GCG ATG GAA AAT GAG GTG \\
7A (exon 13) & TGC CTC CAA TTC TTC ACA G \\
7B (exon 22/23) & CCT CTC CTT TGT TAG ATG CC \\
8A (exon 3) & AGG CAT ACA TCA CAA TTT GG \\
8B (exon 12) & TTG CTC AGA ACT TAT ACC ACG \\
\hline
\end{tabular}

be predisposed to a variety of cancers, and the fibroblasts of AT patients are hypersensitive to ionizing radiation [29]. Although many reports showed the association of ATM mutation with risk of a number of different human malignancies, including prostate cancer, breast cancer, ovarian cancer, B-cell chronic lymphocytic leukemia and mantle cell lymphoma, the underlying molecular mechanism by which ATM gene causes these changes are not well understood [30-35]. There is so far no study showing the association of ATM gene with any solid tumor. There is enormous epidemiological interest in establishing the link of ATM gene abnormality with cancer risk, since the percentage of the ATM heterozygotes is high, and estimated to represent $1.5 \%$ of total population.

We studied the immunostaining characteristics of ATM protein in clinical rhabdomyosarcoma cases and found that a significantly high number of cases lacked the proper ATM gene product ( $41 \%$ in 17 cases). The clinical significance of this finding is unclear at this point. There is high percentage of clinical rhabdomyosarcoma cases associated with p53 gene mutation/deletion. The p53 mutant mice tend to develop rhabdomyosarcoma [29]. P53 is a tumor suppressor regulating cell cycle control and apoptosis, and p53 is one of the many downstream targets of ATM kinase[25,27]. ATM phosphorylate p53 at Serine 15 in response to DNA damage agents [17]. It is unknown how the mutated ATM contributes to pathogenesis of rhabdomyosarcoma in the presence of the mutated p53. In fact, the rhabdomyosarcoma cells Rh30 is known to have $\mathrm{p} 53$ mutation, and is also positive for $\mathrm{t}(2 ; 13)$ chromosomal translocation [11]. Further investigations are needed to address these important questions.
The finding of ATM protein predominantly present in the cytoplasm, but not the nucleus of the tumor sections suggests a different role of ATM in the tumor cells. In the tumor cell lines, the ATM protein is present predominantly in the nucleus. The underlying significance of this finding is unclear. Presumably ATM protein in the cytoplasm may function differently in the tumor cells in vivo from that in the nucleus seen in the cell culture.

The murine ATM was found significantly different in size, although the ATM knockout mice recapitulate the phenotypic features of A-T patients [36]. This species difference may be important in interpreting the data from human cells and from murine cells.

\section{Methods}

\section{Immunohistochemical and immunofluorescent staining}

Human rhabdomyosarcoma tumor specimens were obtained from the Department of Pathology, the Children's Hospital San Diego. All human tissues were formalin fixed, paraffin embedded and were previously used for diagnostic purposes. Current study was approved by the Institutional Review Board at University of California, San Diego (IRB). The specimens were sectioned at 5 micron in thickness, and used for immunohistochemical staining with ATM antibody as described [18]. Briefly, the sections were de-paraffinized in xylene solution, de-hydrated and rehydrated in $100 \%, 90 \%$ and $70 \%$ alcohol. The specimens were immersed in Antigen Retrieval solution (commercially available from Dako Corp. CA) at $90^{\circ} \mathrm{C}$ for 30 minutes to unmask the antigen followed by incubation with primary antibody against ATM protein at $4{ }^{\circ} \mathrm{C}$ overnight. The primary anti-ATM antibody was kindly provided by Dr. Gately and as described previously [18]. 

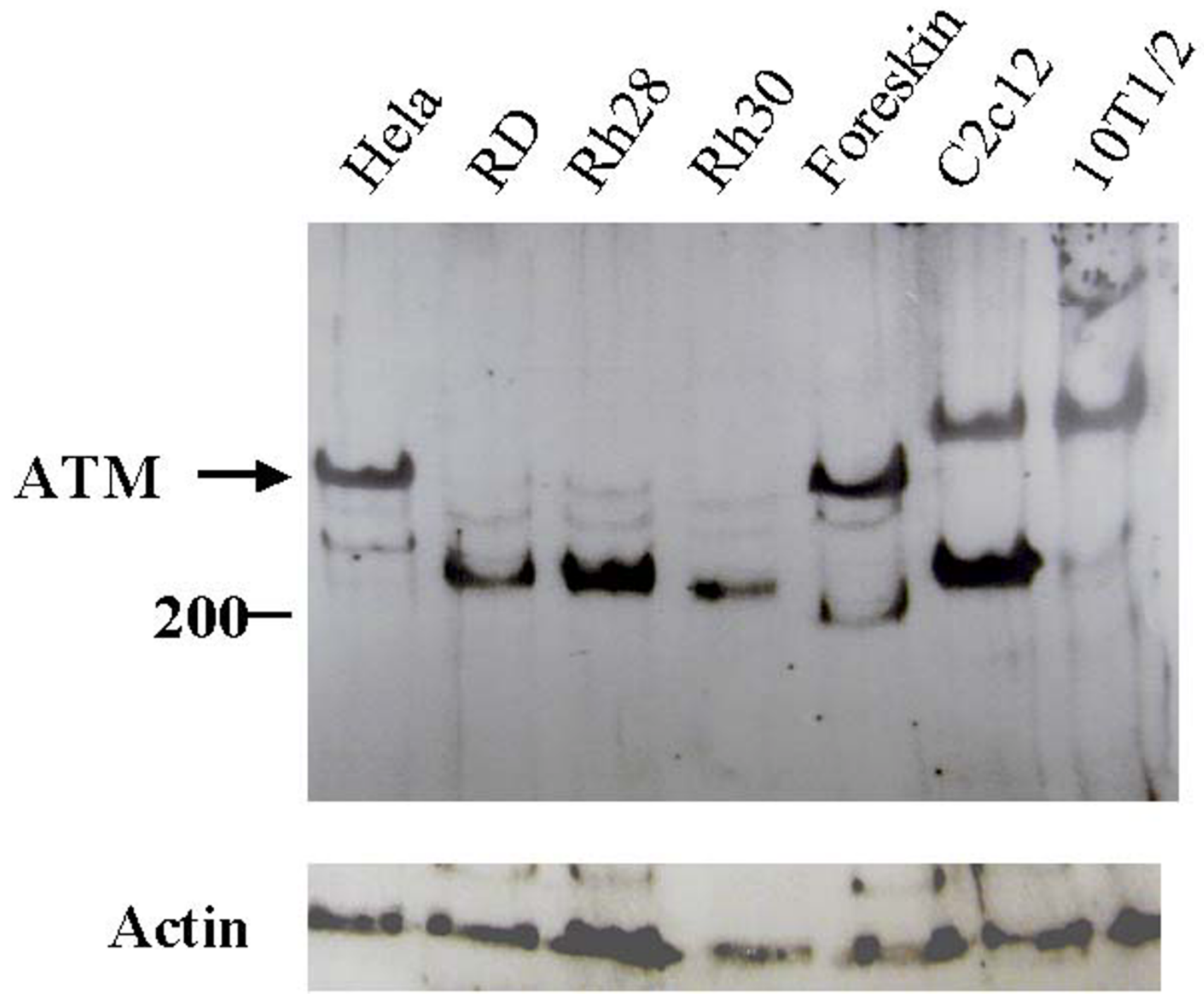

Figure 5

Western blotting of ATM protein in the cultured cells. The whole cell lysates were separated on $4.5 \%$ SDS-PAGE and the ATM protein was detected by using anti-ATM antibody. Lane I: Hela cells, lane 2: RD cells, lane3: Rh28 cells, lane 4: Rh30 cells, lane: 5, normal human foreskin fibroblast cells, lane 6, $\mathrm{C} 2 \mathrm{Cl} 2$ mouse myoblasts, Lane 7. Mouse 10TI/2 fibroblasts.

The second antibody was either immuno-peroxidase conjugated for immunochemical stains or Cy3 conjugated anti-rabbit IgG for immunofluorescent stains (Molecular Probes, OR). For immunofluorescent staining for the tumor cell lines, the tumor cells were cultured on the glass coverslips, fixed by $4 \%$ paraformaldehyde and stained with primary antibody against ATM and MyoD as described [37].

\section{Cell culture, RNA isolation, reverse transcription and PCR} Rhabdomyosarcoma cell lines, such as Rh3, Rh4, Rh 28, RH30 and RD cells were obtained from Dr. Karen Arden, Ludwig Institute of Cancer Research at UCSD. The tumor cell lines were cultured and maintained as described [37]. The total RNA was isolated from the cultured cells using Trizol RNA isolation kit (GBCOL-BRL, Besthesda, MD). The cDNA synthesis was performed using the cDNA synthesis kit (Supersccript, GBCOL-BRL) using random hexamer and oligo-d(T) primers following the instruction from the manufacturer. The total cDNA was directly used 
as templates for PCR amplification for ATM gene using the primer pairs in Table 2 . The primer sequences were based on the ATM sequence (Genbank accession number U33841), and were described for mantle cell lymphoma with slight modification [24]. The primers were synthesized by Sigma-Genosys (Woodlands, Texas). The PCR products were electrophoresed in 1\% agarose gel and visualized using ethidium bromide staining.

\section{Western blotting of ATM protein}

The rhabdomyosarcoma cells are cultured and maintained as described [37]. The cellular proteins were prepared, separated on $4 \%$ polyacrylamide gel and transferred onto nitrocellulose membrane. The immobilized proteins were incubated with anti-ATM antibody[18]. The proteins of interest were detected by enhanced immunochemiluminescence kit from Amersham Life Sciences [37].

\section{Author's contributions}

PZ designed and analyzed the data, and performed large portion of the experiments. KB helped in protein extractions and Western blot analyses. PLP, JF and JW participated with extensive discussion of design and experiments. RON reviewed all the patient's tumor staining and patients cases for diagnoses. All authors read the final manuscripts.

\section{References}

I. Bell RS, Wunder J and Andrulis I Molecular alterations in bone and soft-tissue sarcoma. Can / Surg 1999, 42:259-266

2. Barr FG, Chatten J, D'Cruz CM, Wilson AE, Nauta LE, Nycum LM, Biegel JA and Womer RB Molecular assays for chromosomal translocations in the diagnosis of pediatric soft tissue sarcomas. Jama 1995, 273:553-557

3. Bridge JA, Liu J, Weibolt V, Baker KS, Perry D, Kruger R, Qualman S, Barr F, Sorensen $P$ and Triche $T$ Novel genomic imbalances in embryonal rhabdomyosarcoma revealed by comparative genomic hybridization and fluorescence in situ hybridization: an intergroup rhabdomyosarcoma study. Genes Chromosomes Cancer 2000, 27:337-344

4. Watanabe T, Sakamoto A, Tamiya S, Oda Y, Masuda K and Tsuneyoshi $\mathrm{M}$ H-ras-I point mutation in malignant peripheral nerve sheath tumors: polymerase chain reaction restriction fragment length polymorphism analysis and direct sequencing from paraffin-embedded tissues. Int J Mol Med 2000, 5:605-608

5. Loh WE Jr, Scrable HJ, Livanos E, Arboleda MJ, Cavenee WK, Oshimura $M$ and Weissman BE Human chromosome I I contains two different growth suppressor genes for embryonal rhabdomyosarcoma. Proc Natl Acad Sci U S A 1992, 89:1755-1759

6. Barr FG, Nauta LE, Davis RJ, Schafer BW, Nycum LM and Biegel JA In vivo amplification of the PAX3-FKHR and PAX7-FKHR fusion genes in alveolar rhabdomyosarcoma. Hum Mol Genet 1996, 5:|5-2|

7. Arden KC, Anderson MJ, Finckenstein FG, Czekay S and Cavenee WK Detection of the $\mathbf{t}(2 ; 13)$ chromosomal translocation in alveolar rhabdomyosarcoma using the reverse transcriptase-polymerase chain reaction. Genes Chromosomes Cancer 1996, I 6:254-260

8. Bennicelli JL, Fredericks WJ, Wilson RB, Rauscher FJ 3rd and Barr FG Wild type PAX 3 protein and the PAX3-FKHR fusion protein of alveolar rhabdomyosarcoma contain potent, structurally distinct transcriptional activation domains. Oncogene 1995, II:119-130
9. Biegel JA, Nycum LM, Valentine V, Barr FG and Shapiro DN Detection of the $t(2 ; \mid 3)(q 35 ; q \mid 4)$ and PAX3-FKHR fusion in alveolar rhabdomyosarcoma by fluorescence in situ hybridization. Genes Chromosomes Cancer 1995, I 2:186-192

10. Fredericks WJ, Ayyanathan K, Herlyn M, Friedman JR and Rauscher FJ 3rd An engineered PAX3-KRAB transcriptional repressor inhibits the malignant phenotype of alveolar rhabdomyosarcoma cells harboring the endogenous PAX3-FKHR oncogene. Mol Cell Biol 2000, 20:5019-5031

II. Fredericks WJ, Galili N, Mukhopadhyay S, Rovera G, Bennicelli J, Barr FG and Rauscher FJ 3rd The PAX3-FKHR fusion protein created by the $t(2 ; \mid 3)$ translocation in alveolar rhabdomyosarcomas is a more potent transcriptional activator than PAX3. Mol Cell Biol 1995, I 5: I 522-I535

12. Savitsky K, Sfez S, Tagle DA, Ziv Y, Sartiel A, Collins FS, Shiloh Y and Rotman $G$ The complete sequence of the coding region of the ATM gene reveals similarity to cell cycle regulators in different species. Hum Mol Genet 1995, 4:2025-2032

13. Savitsky K, Bar-Shira A, Gilad S, Rotman G, Ziv Y, Vanagaite L, Tagle DA, Smith S, Uziel $T$ and Sfez $S$ A single ataxia telangiectasia gene with a product similar to PI-3 kinase [see comments]. Science 1995, 268:1749-1753

14. Westphal $\mathrm{CH}$, Rowan S, Schmaltz C, Elson A, Fisher DE and Leder P atm and p53 cooperate in apoptosis and suppression of tumorigenesis, but not in resistance to acute radiation toxicity. Nat Genet 1997, 16:397-40 I

15. Westphal $\mathrm{CH}$, Schmaltz C, Rowan S, Elson A, Fisher DE and Leder P Genetic interactions between atm and p53 influence cellular proliferation and irradiation-induced cell cycle checkpoints. Cancer Res 1997, 57:1664-1667

16. Baskaran R, Wood LD, Whitaker LL, Canman CE, Morgan SE, Xu Y, Barlow C, Baltimore D, Wynshaw-Boris A and Kastan MB Ataxia telangiectasia mutant protein activates c-Abl tyrosine kinase in response to ionizing radiation [see comments]. Nature 1997, 387:516-519

17. Canman CE and Lim DS The role of ATM in DNA damage responses and cancer. Oncogene 1998, 17:3301-3308

18. Gately DP, Hittle JC, Chan GK and Yen TJ Characterization of ATM expression, localization, and associated DNA-dependent protein kinase activity. Mol Biol Cell 1998, 9:236I-2374

19. Brown AL, Lee CH, Schwarz JK, Mitiku N, Piwnica-Worms H and Chung JH A human CdsI-related kinase that functions downstream of ATM protein in the cellular response to DNA damage. Proc Natl Acad Sci U S A 1999, 96:3745-3750

20. Tominaga K, Morisaki H, Kaneko $Y$, Fujimoto A, Tanaka T, Ohtsubo $M$, Hirai M, Okayama $H$, Ikeda $K$ and Nakanishi M Role of human Cds I (Chk2) kinase in DNA damage checkpoint and its regulation by p53. J Biol Chem I999, 274:3 |463-3 |467

21. Zhao S, Weng YC, Yuan SS, Lin YT, Hsu HC, Lin SC, Gerbino E, Song $\mathrm{MH}$, Zdzienicka MZ and Gatti RA Functional link between ataxia-telangiectasia and Nijmegen breakage syndrome gene products [see comments]. Nature 2000, 405:473-477

22. Shiloh $Y$ Ataxia-telangiectasia and the Nijmegen breakage syndrome: related disorders but genes apart. Annu Rev Genet |997, 3 1:635-662

23. Wu X, Ranganathan V, Weisman DS, Heine WF, Ciccone DN, O'Neill TB, Crick KE, Pierce KA, Lane WS and Rathbun G ATM phosphorylation of Nijmegen breakage syndrome protein is required in a DNA damage response [see comments]. Nature 2000, 405:477-482

24. Schaffner C, Idler I, Stilgenbauer S, Dohner H and Lichter P Mantle cell lymphoma is characterized by inactivation of the ATM gene. Proc Natl Acad Sci U S A 2000, 97:2773-2778

25. Wang JY Cellular responses to DNA damage. Curr Opin Cell Biol 1998, I 0:240-247

26. Wang JY Regulation of cell death by the Abl tyrosine kinase. Oncogene 2000, 19:5643-5650

27. Kastan $M B$ and Lim DS The many substrates and functions of ATM. Nat Rev Mol Cell Biol 2000, I:I79-186

28. Kastan MB Cell cycle. Checking two steps. Nature 200 I, 4 I 0:766767

29. Anderson J, Gordon A, Pritchard-Jones K and Shipley J Genes, chromosomes, and rhabdomyosarcoma. Genes Chromosomes Cancer 1999, 26:275-285

30. Fan Z, Chakravarty P, Alfieri A, Pandita TK, Vikram B and Guha C Adenovirus-mediated antisense ATM gene transfer sensitizes 
prostate cancer cells to radiation [In Process Citation]. Cancer Gene Ther 2000, 7:1307-1314

31. Angele $S$ and Hall J The ATM gene and breast cancer: is it really a risk factor? Mutat Res 2000, 462:167-I78

32. Buchholz TA, Weil MM, Story MD, Strom EA, Brock WA and McNeese MD Tumor suppressor genes and breast cancer. Radiat Oncol Investig 1999, 7:55-65

33. Capello D and Gaidano G Molecular pathophysiology of indolent lymphoma [see comments]. Haematologica 2000, 85:19520l

34. Koike M, Takeuchi S, Park S, Hatta Y, Yokota J, Tsuruoka N and Koeffler HP Ovarian cancer: loss of heterozygosity frequently occurs in the ATM gene, but structural alterations do not occur in this gene. Oncology 1999, 56:160-163

35. Schaffner C, Stilgenbauer S, Rappold GA, Dohner H and Lichter P Somatic ATM mutations indicate a pathogenic role of ATM in B-cell chronic lymphocytic leukemia. Blood 1999, 94:748-753

36. Xu Y, Ashley T, Brainerd EE, Bronson RT, Meyn MS and Baltimore D Targeted disruption of ATM leads to growth retardation, chromosomal fragmentation during meiosis, immune defects, and thymic lymphoma [see comments]. Genes Dev 1996, 10:24I I-2422

37. Puri PL, Wu Z, Zhang P, Wood LD, Bhakta KS, Han J, Feramisco JR, Karin $M$ and Wang JY Induction of terminal differentiation by constitutive activation of p38 MAP kinase in human rhabdomyosarcoma cells. Genes Dev 2000, I 4:574-584

Publish with Bio Med Central and every scientist can read your work free of charge

"BioMed Central will be the most significant development for disseminating the results of biomedical research in our lifetime. "

Sir Paul Nurse, Cancer Research UK

Your research papers will be:

- available free of charge to the entire biomedical community

- peer reviewed and published immediately upon acceptance

- cited in PubMed and archived on PubMed Central

- yours - you keep the copyright

Submit your manuscript here:

http://www.biomedcentral.com/info/publishing_adv.asp
BioMedcentral 